\title{
British universities object to idea of year-round terms
}

Birmingham. British universities have reacted warily to the suggestion of changes in the academic year that would include yearround teaching. The government has endorsed the proposal as a way to save money, but many universities fear it would be damaging to research.

The implications of restructuring the traditional three-term academic year, which starts in late September and runs until the end of June, are being analysed by a committee chaired by Lord Flowers, a former rector of Imperial College in London and vice-chancellor of the University of London. The committee's investigation, whose preliminary report was published last week, has been prompted by tests of new academic schedules at several universities, including two 15-week terms instead of three of 10 weeks.

Addressing a conference in Birmingham organized by the Higher Education Funding Council for England (HEFCE) - the new body responsible since 1 April for distributing government grants to England's 140 universities and other higher education institutions - Flowers said that spreading the teaching load more evenly across the year could help to alleviate overcrowding. In addition, if extra teaching resources were made available, the number of students could be increased by introducing an extra term or semester over the summer.

The government is keen for universities to investigate such new teaching patterns in keeping with its commitment to increase participation in higher education from 28 per cent to 33 per cent of school leavers by the end of the decade. John Patten, the Secretary of State for Education, says that there was "no question" of a single blueprint being imposed on all universities but that he is "optimistic that there is scope for considerable progress".

But senior officials from some universities say that their combined capacity for

\section{Changes urged in reimbursement}

London. The vice-chancellors of Britain's principal research universities have asked William Waldegrave, the cabinet minister responsible for science, to make urgent changes in the procedures to claim back funds transferred last year from the former Universities Funding Council (UFC) to the research councils. The government appears eager to resolve the problem, which involves the implementation of new rules on reimbursement for research-related expenses.

The request follows evidence produced by a working group of university finance directors that as much as $£ 25$ million (US $\$ 37$ million) of the $£ 87$ million being transferred during the current financial year may not have been allocated as intended. In particular, much of the money intended to cover the 'new' costs of technical staff and other exceptional items appears to have gone for 'old' costs such as research assistantships and major pieces of research equipment.

Two years ago, the government decided that research councils should pay the full costs of the research they sponsor at universities rather than relying on universities to cover some of the costs through their UFC grants. The government had intended that the money transferred to the research councils should make its way back to universities.

Detailed analysis of the 586 awards received by a sample of 15 universities from the five research councils since the beginning of the year provided no evidence that the transferred money has not been returned.
However the group did find an apparent costs which the universities could have expected to receive back from the research councils under the new arrangements. In addition, only $£ 1.3$ million (rather than an anticipated $£ 8.3$ million) had been requested for the new types of non-staff costs that can now be claimed.

One reason for the discrepancies is that many academics have not been making claims under their grant applications for all the costs which would previously have been covered from university funds. University scientists, in turn, have complained that money can be claimed for technical assistants only if this is for more than 20 per cent of their time, and that research councils have apparently been disallowing a greater proportion of the 'new costs' than of the 'old costs'.

The two sides are planning to meet soon under the aegis of the Advisory Board for the Research Councils to iron out their differences. At the same time, immediate cash flow problems facing several universities as a result of the discrepancies has led to demands for action as soon as possible. In particular, universities, while accepting the need to ensure that their staff are better informed about the new procedures, want the research councils to eliminate the threshold on the amount they can claim for staff salaries and to reduce the thresholds applied to non-staff costs.

David Dickson shortfall of almost $£ 3$ million in the staff

\section{IMAGE UNAVAILABLE FOR COPYRIGHT REASONS}

\section{Patten expects progress.}

teaching and research is already close to its limits. "The whole concept is ludicrous, certainly for research-intensive universities", says Derek Roberts, provost of University College, London.

Officials at both the Universities of Oxford and Cambridge say that they are unlikely to implement the type of radical changes envisaged in the Flowers report. Equally strong opposition - including the threat of strike action - has also come from the Association of University Teachers, which argues that, in the absence of substantial extra funds, requiring teaching during the summer months would undermine the opportunity to carry out research.

Responding to such criticisms, Flowers emphasizes that the changes outtined in his report would not necessarily be harmful to research. For example, he suggests that some institutions would benefit from distributing research more evenly throughout the academic year rather than concentrating it in the summer vacation.

Flowers also argued forcefuily against the introduction of two-year degree courses. Although these might be popular with certain students (for example, mature students keen to reduce the time spent studying for a degree) he expressed doubts that a two-year degree "would provide sufficient time for reflection, field studies and laboratory work" for the majority.

In his address to the funding council, Patten said that he was strongly opposed for both intellectual and financial reasons to the widespread expansion of four-year undergraduate courses, even though these could be justified in exceptional circumstances. He deplores the trend towards adding a fourth year to courses in science subjects to compensate for inadequate teaching in schools, saying that the solution is better science teaching rather than lengthening the undergraduate course. "Longer higher education courses are a luxury we simply cannot afford" he said, adding that the funding councils have been asked to devise measures to discourage any increase in the average length of courses. David Dickson 